\title{
Professional Foreign-Language Training as a Component of Higher Vocational Education
}

\author{
Olga M. Trubitsyna ${ }^{1}$, Olha Kanibolotska ${ }^{2}$, Iryna Y. Zozulia ${ }^{3}$, Alla S. Stadnii ${ }^{3}$ \& Maryna Y. Martynenko ${ }^{4}$ \\ ${ }^{1}$ Department of the Germanic Philology and Methods of Teaching Foreign Languages, Faculty of foreign languages, \\ South-Ukrainian National Pedagogical University named after K. D. Ushynsky, Odesa, Ukraine \\ ${ }^{2}$ Department of Teaching Second Language, Faculty of Foreign Philology, Zaporizhzhia National University, \\ Zaporizhzhia, Ukraine \\ ${ }^{3}$ Department of Linguistics, Faculty of Infocommunications, Radio Electronics and Nanosystems, Vinnytsia National \\ Technical University, Vinnytsia, Ukraine \\ ${ }^{4}$ Philology and Publishing Department, Faculty of Law, Humanity and Social Sciences, Kremenchuk Mykhailo \\ Ostrohradskyi National University, Kremenchuk, Ukraine
}

Correspondence: Olga M. Trubitsyna, South-Ukrainian National Pedagogical University named after K. D. Ushynsky, 26 Staroportofrankivska str., Odesa, 65000, Ukraine.

Received: June 10, 2020

doi:10.5430/ijhe.v9n7p187
Accepted: August 3, 2020

Online Published: August 7, 2020

URL: https://doi.org/10.5430/ijhe.v9n7p187

\begin{abstract}
Obtaining higher vocational education, mastering the practical aspects of the chosen profession, and later work in the specialty are the goals of everyone, who seeks to find their niche in the modern society. Taking in consideration the above, the aim of the scientific article is to study the main aspects of professional foreign-language training as a component of higher vocational education. Methods of theoretical analysis, comparison, description and observation have been used to reveal the purpose of the academic paper. The study was conducted in the article on the examples of studying Ukrainian as a foreign language and English as a foreign language. It has been established that studying Ukrainian as a foreign language is carried out when it is necessary to communicate in private life, as well as in the framework of doing business. In the course of the study it has been established that key aspects of learning English relate to the fact that English is the world's language of doing business, the second most widely spoken language in the world, apart from the mother tongue, and one of the official languages of the world's leading organizations, such as UN, EU, etc. It has been established that currently in Ukraine the following mastery levels of the Ukrainian language are in effect in the process of mastering this academic discipline, namely: elementary, basic, low-intermediate, high-intermediate, advanced and proficient level of knowledge of the Ukrainian language as a foreign. It has been determined that professional foreign language training of students at institutions of higher professional education in the direction of "English as a foreign language" both in Ukraine and abroad involves students gaining the following levels of English in the process of mastering the discipline, namely: Beginner, Elementary English, Intermediate English, Upper-Intermediate English, Advanced English, Proficiency English.
\end{abstract}

Keywords: professional foreign-language training, higher vocational education, Ukrainian as a foreign language, English as a foreign language

\section{Introduction}

According to the analysis of modern teaching practice at higher professional educational institutions, currently the direction of studying foreign languages, especially English, is widely popular among a number of different educational areas.

"Intercultural communicative competences" are becoming more and more widespread in foreign language training (Yang, Xiang \& Chun, 2018). An intercultural approach is applied in the professional training foreign languages through the growth of multilingual students (Calafato, 2019), which is especially evident in EU countries. Students' mobility is growing, and as a result, the mobility of professionals through the needs of the labour market is also increasing; the convergence of policies in providing professional foreign language training takes place due to the lack of specialists in the labour market and economic goals of countries (Pérez-Llantada, 2018). Training formats are becoming flexible and student-cantered (Arrosagaray, González-Peiteado, Pino-Juste \& Rodríguez-López, 2019). 
Professional foreign-language training of students at institutions of higher professional education is aimed at acquiring professional knowledge by students, as well skills and abilities of speaking a foreign language. However, as study has revealed, currently there is often a problem of communication with native speakers in the process of studying foreign languages. Therefore, in order to improve the results of the studying the educational material and gaining deeper knowledge by students in the sphere of communication with native speakers, many institutions of higher professional educations, providing professional foreign language training for students, participate in various internship and exchange programs.

Taking in consideration the above, the purpose of the academic paper is to study the main aspects of professional foreign-language training as a component of higher vocational education. In the context of achieving the purpose of the academic paper, a number of tasks need to be solved, namely:

1) To reveal the theoretical aspects of professional foreign language training as a component of higher professional education;

2) To present the features of professional foreign language training on the example of studying Ukrainian as a foreign language and English as a foreign language;

3) To consider ways to improve the results of learning foreign languages in the context of professional foreign language training.

\section{Literature Review}

In the framework of conducting the theoretical analysis of the key aspects of professional foreign-language training as a component of higher vocational education, the positions of leading scientists and practicing educators, who have worked and are working on this issue, should be studied and considered.

In the process of studying the features of professional foreign-language training as a component of higher vocational education, emphasizes the allocation of six levels of learning foreign language. The first level is aimed at the basic definition of the primary functions of language and communication, in particular. At the second level, the primary functions of language are divided into varieties (for example, communication in oral and written forms). The third level of education focuses on such elements of learning, as: listening, speaking, reading and writing. At the same time the main directions of the fourth level include: information topics of communication, professional and information topics of communication, everyday topics of communication, newspaper and information topics of communication and the basic provisions of research and scientific activities. At the fifth stage of training the conversational, journalistic and scientific style of speech is formed, and at the last sixth stage - the ability to communicate in everyday situations of personal, social-political and professional-scientific nature. The study of a foreign language is one of the key goals of a higher education institutions' functioning. Furthermore, the process of learning a foreign language should not be separated from the key specialization, according to which students obtain their future profession (Sura, 2015).

The results of foreign-language training in the system of higher vocational education depend first of all on the level of qualification and professional competences of teaching staff. Herewith, Viktorova (2014) claims that educators should have complete mastery in the teaching material of foreign language curriculum. The quality level of special foreign language training primarily depends on the educational, research, methodological and organizational and managerial actions of higher educational institutions, forasmuch as professional foreign language training of a higher educational institution should be aimed at studying and constant improvement of a foreign language's knowledge by students. Herewith, the scholar notes that the effectiveness of the process of professional foreign language training, which is carried out by the institution of higher education, to a great extent depends on the availability of scientific and pedagogical staff. Forasmuch as a higher educational institution with highly qualified scientific and pedagogical staff has significant advantages in achieving a positive result from professional foreign language training of students, in contrast to other higher educational institutions, which scientific and pedagogical staff are not so qualified.

In the context of studying, numerous curricula of Ukrainian as a foreign language are necessary for the educational process in the preparatory departments of Ukrainian higher educational institutions. Students, in the course of study of this discipline, will receive the necessary (basic) level of knowledge of the Ukrainian language after graduating from such departments, as well as acquire communication skills and abilities in various areas of educational, scientific, social-cultural and social-political spheres. In the course of developing a curriculum for Ukrainian as a foreign language, includes a number of tasks in the basis of this program, required by the curriculum in the context of studying Ukrainian as a foreign language at special preparatory faculties of higher educational institutions in Ukraine. Thus, the curriculum requires the formation of foreign students' discursive, activity, linguistic, speech and 
social-cultural competences. In addition, students should master various means of the Ukrainian language that are necessary for communicative speech, as well as study the basic speech and language concepts, learn the norms of the Ukrainian literary language and culture of communication (Ivanyshyn, 2016).

In the course of studying the peculiarities of the implementation of the State Standard from the Ukrainian language as a foreign language, which are considered and studied by Mazuryk (2010), the researcher emphasizes the allocation of the following proficiency levels of Ukrainian as a foreign language:

1) Elementary proficiency level of Ukrainian as a foreign language;

2) Basic proficiency level of Ukrainian as a foreign language;

3) Low-intermediate proficiency level of Ukrainian as a foreign language;

4) High-intermediate proficiency level of Ukrainian as a foreign language;

5) Advanced proficiency level of Ukrainian as a foreign language;

6) Proficient proficiency level of Ukrainian as a foreign language.

Dialogical speech is an important element of communication activity in the study of Ukrainian as a foreign language. According to the scientist's point of view, dialogical speech is a process of conversational interrelation of two or more participants in communication process. Furthermore, the role of dialogical speech centers around promoting the emergence of students' verbal incentives in order to enhance the learning process and the acquisition of grammatical and lexical material. There are different types of dialogues that students should obtain in the context of mastering the basic level of Ukrainian as a foreign language, namely: a dialogue of etiquette character, a dialogue arrangement, a dialogue-inquiry and a dialogue of exchange of opinions or messages. The researcher also emphasizes that in classes on the study of the Ukrainian language as foreign language teachers should pay considerable attention primarily to dialogic speech and improving students' communication skills (Solodar, 2011).

Currently, in the context of studying Ukrainian as a foreign language, first of all one should pay attention to the study of the logical and grammatical component of the Ukrainian language system. The scientist also notes that special attention in the process of studying Ukrainian as a foreign should be given to (Shelest, 2018):

1) Highlighting the main stages of learning;

2) Provision of the practical orientation of the educational process;

3) Applying a functional approach in order to select and present appropriate language learning material;

4) Studying morphology and vocabulary of Ukrainian as a foreign language on a syntactic basis;

5) Presentation of educational material through a situational-thematic cycle of tasks.

Regarding the theoretical principles of learning English as a foreign language, the leading role in the process of learning English as a foreign language is played by culture, which is connected with the peculiarities of the English language. In the course of the study, Choudhury (2014) states that studying cultural aspects and communicating up-close and personal with native English speakers is one of the benefits of achieving success in learning English as a foreign language.

\section{Data and Methodology}

The research has been conducted on the basis of the analysis of curricula and disciplines offered by tertiary educational institutions of Ukraine. At the first stage of the research, data on tertiary educational institutions have been collected, which offer foreign language training within the curricula. At the second stage of the research, an analysis of the results of foreign language training, offered by universities, based on information from the official websites of each university has been conducted. The amount of hours for practical training and independent training, topics, levels of training has been analysed in the research.

The analysis of educational programs and courses in higher education institutions of Ukraine for the period 2018/2019 academic year was used to conduct the study. Higher education institutions are selected according to the ranking of Ukrainian universities. The consolidated ranking of higher education institutions of Ukraine provides ranking places within the country of each of the fifteen universities and contains the following indicators: overall rating, Top-200 Ukraine, Webometrics, Scopus, final score.

The rating was used to analyze the courses and disciplines after the selection of higher education institutions. They offer the courses and disciplines in order to identify the quality of professional foreign language training, teaching approaches and the level of consideration of the latest trends in clients' necessities in foreign language training. 
The methodological basis of the scientific article includes a number of curricula and disciplines, which are offered, for example, by such organizations and institutions of higher education, as: the Centre for Language Development, Kharkiv National University of Economics named after Simon Kuznets, Kharkiv National Automobile and Highway University, National Technical University of Ukraine "Kyiv Polytechnic Institute" in order to provide professional foreign language training for applicants (students) in the context of learning Ukrainian as a foreign language, as well as National Technical University "Dnipro Polytechnic" in the context of learning English as a foreign language. In addition, the methodological basis of studying the Ukrainian language as a foreign language is also based on the State Standard of Ukraine (Ministry of Education and Science of Ukraine, 2018).

Theoretical and practical principles of research of professional foreign-language training as a component of higher vocational education in a scientific article have been considered using the methods of theoretical analysis, comparison, description and observation.

\section{Results of the Research}

In In the context of revealing the practical principles of professional foreign-language training as a component of higher vocational education, key issues should be investigated and a comparative analysis of the peculiarities of learning a foreign language on the example of Ukrainian as a foreign language and English as a foreign language should be carried out.

Studies prove that most often studying Ukrainian as a foreign language is carried out when it is necessary to communicate in private life, as well as in the framework of doing business.

In Ukraine, numerous educational institutions study Ukrainian as a foreign language, among which the Centre for Language Development (2020) deserves special attention, offering a number of courses on learning Ukrainian as a foreign language. Thus, one of the most common courses attended by students is the Business Ukrainian course.

The curriculum of the discipline "Ukrainian as a foreign language", presented by Kharkiv National Economic University named after Simon Kuznets (2020) states that according to the results of studying this discipline, students will be able to:

1) Receive basic knowledge on key aspects of preparation of the scientific text, which should be presented following the results of the received scientific-educational and research activity;

2) Acquire skills for scientific text analysis;

3) Acquire the ability to speak Ukrainian logically and correctly, according to the principles of a scientific style.

It should also be noted that the studying the above mentioned curriculum will contribute to the formation of linguistic, informational, axiological, communicative and professional competences of students.

At the same time, the curriculum of the discipline "Ukrainian as a foreign language", developed by the Kharkiv National Automobile and Highway University (2018) states that students (graduates) after studying this discipline will gain knowledge about the basic elements of the phonetic system of the Ukrainian language, lexical and grammatical construction of the Ukrainian language, which is necessary for communication not only in the educational and professional sphere, but also in everyday life. Students study this discipline during 934 hours, of which 402 hours are practical and seminar classes, 220 hours - independent work of students and only 6 hours computational and graphic work.

On the other hand, according to the curriculum of the discipline "Ukrainian as a foreign language" developed by the Faculty of Linguistics of the NTUU "Kyiv Polytechnic Institute" (2015) students (graduates) should pass 6 credit modules:

1) Ukrainian language with elements of professionally oriented communication;

2) Introduction to the Ukrainian language of professionally oriented communication;

3) Ukrainian language of professional orientation (the first stage of study);

4) Ukrainian language of professional orientation (the second stage of study);

5) Ukrainian language of professionally oriented communication (the first stage of studying business speech);

6) Ukrainian language of professionally oriented communication (the second stage of studying business speech).

According to the results of research conducted concerning studying Ukrainian language in different countries, Shaghinjan (2018) proves that currently studying the Ukrainian language is carried out at schools of 47 countries in the world. It should be emphasized that studying the Ukrainian language is mainly carried out on extracurricular 
lessons, as well as at weekend schools. The financing of the educational process for provision studying the Ukrainian language is mainly carried out from municipal budgets. This type of funding for the training process specified is available in such countries, as: Bosnia and Herzegovina, Latvia, Poland, Slovakia, Romania, Moldova, Kazakhstan and Kyrgyzstan, as well as in other countries. However, for instance, studying the Ukrainian language in the educational process in Turkey is financed from the school budget, to which the municipal government is out of all relation. Despite this fact, it should be noted that the financing of the educational process for studying the Ukrainian language is also provided by the society, the church or directly by parents. Canada, the United States, and Brazil are the examples of countries with this type of funding, as they have the largest numbers of ethnic migrants from Ukraine. For the matter of higher vocational education, studying Ukrainian as a foreign language is conducted in 36 countries, including: Australia, Azerbaijan, Brazil, Great Britain, Greece, Georgia, Kyrgyzstan, China, Macedonia, Germany, South Korea, Slovakia, the USA, Tajikistan, Turkey, Hungary, Finland, France, the Czech Republic and Croatia, which have 58 departments for training of future teachers of the Ukrainian language.

At the same time, the curriculum of the academic discipline "Ukrainian as a Foreign Language", developed by Vasutynska (2019) states that the following methods are applied in the process of studying the Ukrainian language as a foreign language by the students, namely: an explanatory and illustrative method, reproductive method, fragmentary-search method, problem-based and search method, research method, explanation method and conversation method. Concerning teaching methods, the learning process is formed by applying innovative and traditional methods. In turn, the assessment of students' knowledge and skills based on the results of studying the discipline "Ukrainian as a foreign language" is carried out in the following forms: current control over the results of written and oral answers, conducting solitary and control works, tests, colloquiums, and ultimately - through passing the exam.

For instance, a typical curriculum of Ukrainian as a foreign language, developed by Ivanyshyn (2016) specifically for the preparatory faculties of higher educational institutions in Ukraine includes three concentric circles, according to which students acquire knowledge about the appropriate level of mastery of the Ukrainian language as a foreign language. According to the first concentric circle, which corresponds to the initial (elementary) level of mastering the Ukrainian language as a foreign language (A1), students should pass 150 practical and 70 hours of independent work. According to the second concentric circle, which corresponds to the basic level of mastering the Ukrainian language as a foreign language (A2), students should pass 300 practical and 130 hours of independent work. As for the third concentric circle, which corresponds to the intermediate level of mastery of the Ukrainian language as a foreign language (B1), the students should complete a course consisting of 270 practical and 160 hours of independent work.

Herewith, the content of the curriculum developed by Ivanyshyn (2016) is based on 17 blocks, which provide for the consideration of various communicative topics.

It should be noted that in Ukraine, in accordance with the requirements of Council of Europe, an appropriate standard for studying Ukrainian as a foreign language has been developed. Thus, in the State Standard of Ukraine it is noted that the basic purpose of its direction is to obtain the possibility of recognition of Ukrainian certificates not only in European Union but also throughout the world (Ministry of Education and Science of Ukraine, 2018).

Based on the information represented in the State Standard of Ukraine "Ukrainian as a foreign language. Levels of general proficiency and diagnostics", the specifics of studying Ukrainian as a foreign language, English as a foreign language and, accordingly, the levels of proficiency in a foreign language according to the requirements of Council of Europe should be presented in Figure 1.

Thus, according to the elementary level of proficiency of the Ukrainian language as a foreign language, the applicant (student) should acquire knowledge about the structure and system of the Ukrainian language, as well as be able to communicate in a limited (brief) manner on standard (everyday) situations. According to the basic level of proficiency of the Ukrainian language as a foreign language, the applicant (student) should acquire basic knowledge of the Ukrainian language and be able to consciously communicate in standard (everyday) situations that are necessary in order to stay freely in Ukraine for tourism, educational or cultural purposes (except for the implementation of any type of activity). The low-intermediate level of proficiency of the Ukrainian language as a foreign language certifies the presence of the necessary knowledge of the applicant (student) within the implementation of extensive communication in standard (everyday) situations in order to conduct educational (except for faculties that provide university training), educational, consulting, commercial (business) or other legal (legitimate) activities throughout Ukraine. In turn, an high-intermediate level of proficiency of the Ukrainian language as a foreign language is characterized as an effective level of proficiency and allows the applicant (student) to communicate effectively in the Ukrainian professional environment on the basis of the acquired speech skills, 
while obtaining a master's level, which allows the applicant (student) to teach Ukrainian language in a general communicative direction in the future. At the same time, the advanced level of proficiency in Ukrainian as a foreign language is characterized as an active level of proficiency and reflects the ability of the applicant (student) to communicate competently in the Ukrainian professional environment, to use mastery of speech skills for teaching Ukrainian in general communication. As for the proficient level of the Ukrainian as a foreign language, this level is characterized as professional one and reflects the ability of the applicant (student) to communicate independently in the Ukrainian professional environment, creatively and freely use the acquired knowledge of Ukrainian, as well as teach Ukrainian professionally (Mazuryk, 2010).

Regarding studying English as a foreign language, it is worth noting the following. Studies show that English is one of the most widely spoken languages in the world, as it is spoken by a large number of the world's population. It has been established that currently almost every fifth person has the corresponding ability to speak English.

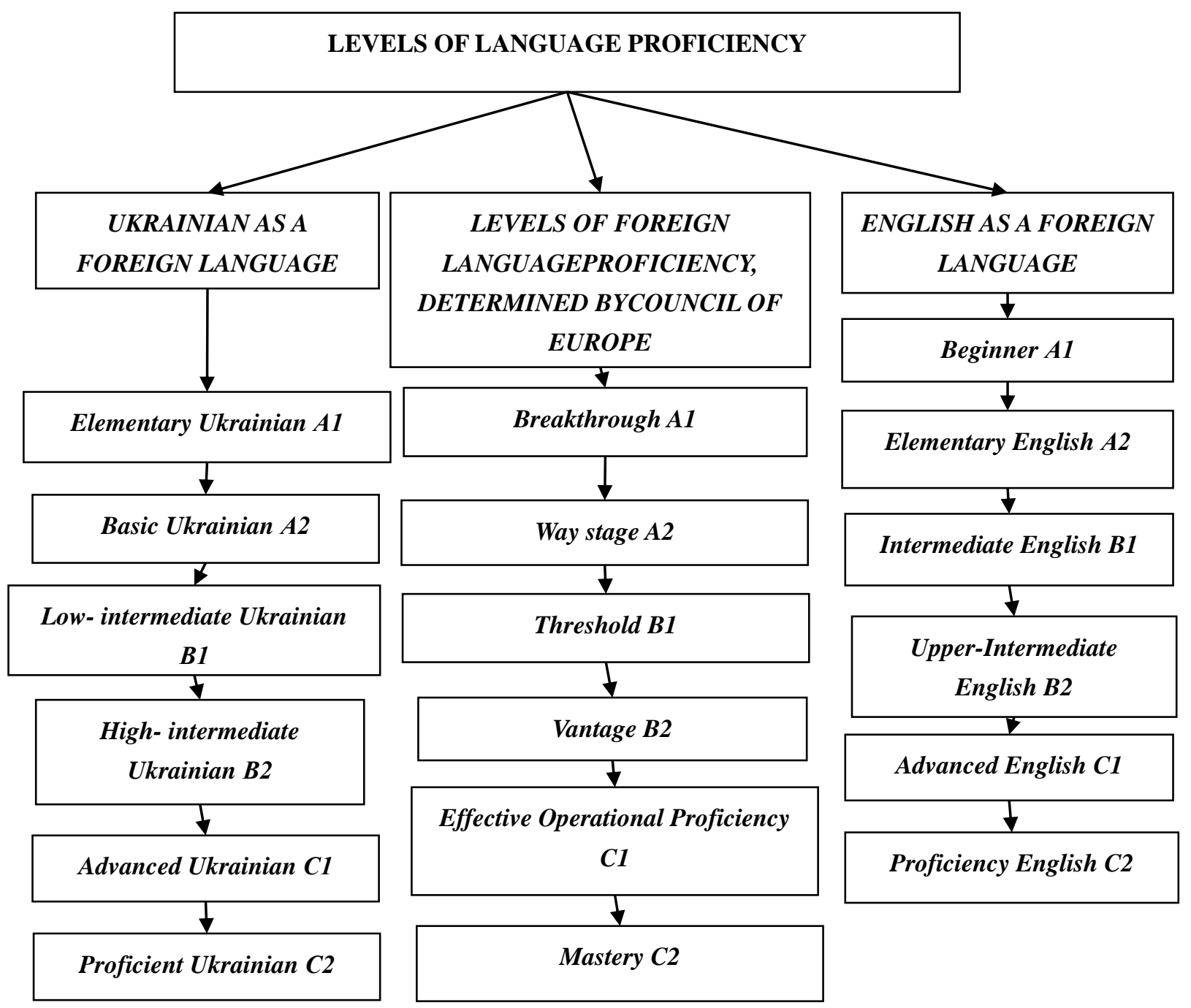

Figure 1. Features of proficiency levels of Ukrainian as a foreign language, English as a foreign language and proficiency levels of a foreign language determined by Council of Europe (Ministry of Education and Science of Ukraine, 2018)

Taking this into consideration, Ash (2015) identifies the following basic reasons that are the basis for learning English as a foreign language, namely:

1) English is the world language of doing business;

2) English is the second spoken language all over the world, with the exception of the mother tongue;

3) English is one of the official languages of the world's leading organizations, such as UN, EU, etc. 
At the same time, according to the curriculum of the discipline "Foreign (English) language for professional communication", developed by the National Technical University "Dnipro Polytechnic" (2020), in the context of studying this discipline, students (graduates) are expected to be able to:

1) Communicate effectively on professional topics;

2) Discuss personal learning experience, research experience or work experience;

3) Exchange interesting information received from media sources;

4) Hold discussions on typical issues related to the professional environment, as well as to hold meetings;

5) Demonstrate the results of their own activities in practice;

6) Demonstrate their skills based on the results of independent work;

7) Think critically;

8) Be open to the development of new knowledge.

In order to ensure the proper level of students' mastery of the English language, currently higher educational institutions around the world are actively involved in various student internship programs abroad.

Thus, based on the research of Karlevitz (2019) world-renowned internship programs, one of the activities of which is studying English, are as follows:

1) Global Volunteer;

2) Global Talent;

3) Globalink Research Internship;

4) Erasmus Mundus;

5) Fulbright Graduate Student Program.

Also, in addition to the internship programs mentioned above, for which one of the items provides for students to study a foreign language, it is necessary to add to this list UK: Volunteer Internship Programme and English + Work Experience.

\section{Discussion}

In the course of the research it has been found out that most often studying Ukrainian as a foreign language is carried out when it is necessary to communicate in private life, as well as in the framework of doing business.

In addition, the key aspects of learning English concern the fact that English is the world language of doing business, the second language spoken in the world with the exception of the mother tongue; it is one of the official languages of the world's leading organizations, such as UN, EU, etc.

According to the results of the study, it has been established that the quality level of special foreign language training primarily depends on the educational, research, methodological and organizational and managerial actions of higher educational institutions, forasmuch as professional foreign language training of a higher education institution should be aimed at training and continuous improvement of students' knowledge of the foreign language (both for learning Ukrainian as a foreign language and for learning English as a foreign language).

In addition, the authors conducted the study of the features of curricula and disciplines that are offered for example by such organizations and institutions of higher education, as: the Centre for Language Development, Kharkiv National University of Economics named after Simon Kuznets, Kharkiv National Automobile and Highway University, National Technical University of Ukraine "Kyiv Polytechnic Institute" in order to provide professional foreign language training for applicants (students) in the context of learning Ukrainian as a foreign language, as well as National Technical University "Dnipro Polytechnic" in the context of learning English as a foreign language.

In the framework of studying the practical aspects of professional foreign language training of students at institutions of higher professional education in the direction of "Ukrainian as a foreign language" it has been established that currently in Ukraine there are such levels of the Ukrainian language acquisition in the process of mastering this discipline, namely: elementary proficiency level of Ukrainian as a foreign language; basic proficiency level of Ukrainian as a foreign language; low-intermediate proficiency level of Ukrainian as a foreign language; high-intermediate proficiency level of Ukrainian as a foreign language; advanced proficiency level of Ukrainian as a foreign language; proficient proficiency level of Ukrainian as a foreign language. 
At the same time, professional foreign language training of students by institutions of higher professional education in the field of "English as a foreign language" both in Ukraine and abroad provides students with the following levels of English in the process of mastering the discipline, namely: Beginner, Elementary English, Intermediate English, Upper-Intermediate English, Advanced English, Proficiency English.

In the process of improving the results of learning materials and gaining deeper knowledge by students in the sphere of communication with native English speakers, numerous institutions of higher professional education, providing professional foreign language training of students, participate in various internship and exchange programs, which are quite popular today, namely: Global Volunteer, Global Talent, Globalink Research Internship, Erasmus Mundus, Fulbright Graduate Student Program, UK: Volunteer Internship Programme, English + Work Experience.

\section{Conclusion}

Therefore, the study of theoretical and practical principles of professional foreign language training as a component of higher vocational education has shown that currently training of applicants of higher vocational education is carried out in accordance with specially designed curricula. In Ukraine, as in other countries of the world, studying the foreign language by students takes place in accordance with the established requirements of Council of Europe. According to the results of the study, it has been established that the level of assessment of foreign language knowledge and mastery (for instance, Ukrainian as a foreign language and English as a foreign language) should correspond to such levels of mastery of a foreign language as: Breakthrough, Waystage, Threshold, Vantage, Effective Operational Proficiency, Mastery Council of Europe.

It has also been established that the curricula of studying the Ukrainian language as a foreign language provide for the formation of discursive, activity, linguistic, speech and social-cultural competences of foreign students. In addition, after studying this discipline, students gain knowledge about the basic elements of the phonetic system of the Ukrainian language and lexical and grammatical structure of the Ukrainian language, which is necessary for communication not only in the educational and professional sphere, but also in everyday life.

The studies conducted in the academic paper also have proved that the primary basis for studying English as a foreign language is that English is the world language of doing business, it is the second, with the exception of the mother tongue, spoken language all over the world and one of the official languages of the leading organizations of the world, such as UN, EU.

\section{References}

Arrosagaray, M., González-Peiteado, M., Pino-Juste, M., \& Rodríguez-López, B. (2019). A comparative study of Spanish adult students' attitudes to ICT in classroom, blended and distance language learning modes. Computers \& Education, 134, 31-40. https://doi.org/10.1016/j.compedu.2019.01.016.

Ash, G. (2015). Top 5 Reasons to Study English as a Second Language. Study International. Retrieved from https://www.studyinternational.com/news/top-5-reasons-to-study-english-as-a-second-language/

Calafato, R. (2019). The non-native speaker teacher as proficient multilingual: A critical review of research from 2009-2018, Lingua, 227, 102700. https://doi.org/10.1016/j.lingua.2019.06.001

Centre for Language Development. (2020). Ukrainian language as foreign language at the Centre for Language Development. Retrieved from https://ruslang.kiev.ua/ukrainian-language-courses.html

Choudhury, R. U. (2014). The role of culture in teaching and learning of English as a foreign language. Express, an International Journal of Multi Disciplinary Research, 1(4), 1-20.

Faculty of Linguistics of the NTUU "Kyiv Polytechnic Institute" (2015). The curriculum of the discipline "Ukrainian as a foreign language". Retrieved from http://kmp.fl.kpi.ua/uk/node/171

Ivanyshyn, H. (2016). Typical program of Ukrainian language as a foreign one for training faculties of the Ukrainian HEIs: Teory and practice of composing. Scientific notes of the V. H Hnatiuk TNPU. Series: Pedagogy, 4, 163-169.

Karlevitz, M. (2019). Internship abroad. Top 5 most popular programs (In English and not). Green Forest Journal. Retrieved

from https://greenforest.com.ua/ua/journal/read/stazhirovki-za-granicej-top-5-samyh-populyarnyh-angloyazychnyh-ine-tolko-programm

Kharkiv National Automobile and Highway University. (2018). The curriculum of the discipline "Ukrainan as a $\begin{array}{ll}\text { foreign language”. } & \text { Retrieved } \\ \text { http.//files khadi.kharkov.ua/pidgotovki-inozemnikh-gromadyan/filologiji/item/1294; }\end{array}$

from http://files.khadi.kharkov.ua/pidgotovki-inozemnikh-gromadyan/filologiji/item/12945-navch-prog-ukr.html 
Kharkiv National Economic University named after Simon Kuznets (2020). The curriculum of the discipline "Professional Ukrainian as a foreign language. The backgrounds of communication". Retrieved from https://www.hneu.edu.ua/wp-content/uploads/2020/03/Programa-Fahova-ukrayinska-mova-yak-inozemna.-Osn ovy-komunikatsiyi-2020.pdf

Mazuryk, D. (2010). National standard of Ukrainian for foreigners (from theory to practice). Theory and Practice of Teaching Ukrainian as a Foreign Language, 5, 10-14.

Ministry of Education and Science of Ukraine (2018). The MES offers a state standard for Ukrainian language as a foreign one for the public discussion. Retrieved from https://mon.gov.ua/ua/news/mon-proponuye-do-gromadskogo-obgovorennya-derzhavnij-standart-z-ukrayinskoy i-movi-yak-inozemnoyi

National Technical University "Dnipro Polytechnic" (2020). The curriculum of the discipline "Foreign (English) language for professional communication”. Retrieved from http://ep3.nuwm.edu.ua/id/eprint/14450

Pérez-Llantada, C. (2018). Bringing into focus multilingual realities: Faculty perceptions of academic languages on campus. Lingua, 212, 30-43. https://doi.org/10.1016/j.lingua.2018.05.006

Shaghinjan, T. (2018). Where and how people learn Ukrainian in different countries of the world. Segodnya. ua. Retrieved from https://www.segodnya.ua/ua/world/europe/gde-i-kak-uchat-ukrainskiy-yazyk-v-raznyh-stranah-mira-1151736.ht $\mathrm{ml}$

Shelest, H. U (2018). Learning Ukrainian as a foreign language: Problems, new methods and perspectives. Transcarpathian Philological Studies, 1(3), 51-55.

Solodar, L. V. (2011). Dialogical speech as a main kind of speaking activity in learning Ukrainian as a foreign language. The Bulletin of Vinnytsya Polytechnical Institute, 2, 163-167.

Sura, N. A. (2015). Foreign language professional training as a part of professional higher education. The Bulletin of $V$. Sukhomlynsky Mykolaiv National University. Pedagogical sciences, 1(48), 296-300.

Vasutynska, N. I. (2019). Program of the discipline "Ukrainian as a foreign language" for training the foreign students of the training department. Rivne, Ukraine: National University of Water and Environmental Engineering.

Viktorova, L. (2014). Foreign language training of students in specialized HEIs. Problemy pidhotovky suchasnoho vchytelia, 9(2), 298-305.

Yang, G., Xiang, H., \& Chun, L. (2018). CSL teachers' cognition in teaching intercultural communicative competence. System, 78, 224-233. https://doi.org/10.1016/j.system.2018.09.009 